\title{
Cu(II) Adsorption on Modified Bentonitic Clays: Different Isotherm Behaviors in Static and Dynamic Systems
}

\author{
Ambrósio Florêncio de Almeida Neto ${ }^{a *}$, Melissa Gurgel Adeodato Vieira ${ }^{\mathrm{b}}$, \\ Meuris Gurgel Carlos da Silva ${ }^{\mathrm{a}}$ \\ ${ }^{\mathrm{a}}$ Department of Thermofluidynamics, School of Chemical Engineering, \\ State University of Campinas - UNICAMP, Av. Albert Einstein, 500, \\ Cidade Universitária "Zeferino Vaz", CEP 13083-852, Campinas, SP, Brazil \\ ${ }^{b}$ Department of Chemical Processes, State University of Campinas - UNICAMP, \\ Av. Albert Einstein, 500, Cidade Universitária "Zeferino Vaz", \\ CEP 13083-852, Campinas, SP, Brazil
}

Received: July 26, 2011; Revised: September 16, 2011

\begin{abstract}
$\mathrm{Cu}$ (II) removal equilibrium from aqueous solutions using calcined clays "Bofe" and "Verde-lodo" has been studied by batch and fixed-bed in static and dynamic systems, respectively. Analyses were performed for physicochemical characterization of clays using the techniques: X-ray fluorescence (XRF), thermogravimetry (TG), $\mathrm{N}_{2}$ adsorption (BET) and Cationic Exchange Capacity (CEC). Batch experiments were performed at a constant temperature, adjusting the $\mathrm{pH}$ of the solution in contact with clays. Adsorption assays in fixed bed were conducted at the flow rate determined through mass transfer zone (MTZ). Langmuir and Freundlich models were adjusted to equilibrium data. The results of characterization indicated that the temperature of $500{ }^{\circ} \mathrm{C}$ is best suited for the calcination of the clays. The maximum adsorption capacity was higher for dynamic system than fixed bed compared to static system, enhancing from 0.0748 to 0.1371 and from 0.0599 to $0.22 \mathrm{mmol}^{-1} \mathrm{~g}^{-1}$ of clay for "Bofe" and "Verde-lodo", respectively.
\end{abstract}

Keywords: adsorption, heavy metal removal, bentonitic clay

\section{Introduction}

Clays and minerals such as montmorillonite, vermiculite, illite, kaolinite and bentonite are known as alternative materials used to adsorption of heavy metal due to several economic advantages ${ }^{1-9}$ and their intrinsic properties, such as large specific surface area, excellent physical and chemical stability and properties structural and surface ${ }^{10}$. Other low-cost adsorbents have been investigated, mainly using bioadsorbents, such as algae ${ }^{11}$ and chitosan ${ }^{12}$. However, experiments carried out in fixed bed presented limited results. Bentonite clays are widely used as barriers to avoid subsoil and underground landfill water contamination by leaching containing heavy metals.

Although the results obtained in metal removal using clays are significant and promising, a better understanding of these results is still needed. Studies already performed on Brazilian calcined clay (Bofe type) in the removal of nickel ${ }^{13,14}$ have shown the need for further research on heavy metal removal comparing adsorption capacity in both static and dynamic systems. The high load of galvanic toxic waste in the Southeast of Brazil is composed mainly of salts of cyanide and heavy metals such as copper, among others; these can be present in soluble and insoluble forms. Therefore, research on the mechanisms of removal of copper are required for remediation of this contaminant.

*e-mail: ambrosio@feq.unicamp.br
In order to evaluate the removal of copper using Bofe and Verde-Lodo (VL) bentonite clays as adsorbents thermally modified, the adsorption experiments were conducted using static (batch) and dynamic systems (fixed-bed). Both clays have been chosen due to their relevant adsorptive properties ${ }^{13}$ and abundance in the Brazil. Modified clays have shown enhanced adsorption capacity.

\section{Experimental}

\subsection{Adsorbents}

Two types of bentonite clays "Bofe" and "Verde-lodo (VL)" from the Northeastern region of Brazil (Boa Vista-PB) were used as adsorbents. Initially, a study was conducted with both raw clays. However, these clays were not used in fixed bed as adsorbents due to their solubility. The clays were prepared by size classification and calcined at $500{ }^{\circ} \mathrm{C}$ for 24 hours in order to increase their mechanical resistance, dehydroxylation and to eliminate some impurities. In some cases, the adsorption capacity can also be enhanced on modified bentonitic clays. The temperature of calcination was determined by thermogravimetric analysis for samples Bofe and VL clays at a heating rate of $10{ }^{\circ} \mathrm{C} / \mathrm{min}$ in air atmosphere. 


\subsection{Metal adsorbate}

The adsorption tests were performed using an aqueous solution in $15.74 \mathrm{mmol} . \mathrm{L}^{-1}$ of copper metal, prepared dissolving appropriate amount of $\mathrm{Cu}\left(\mathrm{NO}_{3}\right)_{2} \cdot 3 \mathrm{H}_{2} \mathrm{O}$ in deionized water to desired concentrations.

The $\mathrm{Cu}(\mathrm{II})$ solution $\mathrm{pH}$ was maintained at a level lower, minimizing the precipitation in to assure the occurrence of the adsorption process and avoiding the chemical precipitation of copper ions in the hydroxide form $\left(\mathrm{Cu}(\mathrm{OH})_{2}\right)$. The $\mathrm{pH}$ of the solutions was measured with $\mathrm{pH}$-meters and it was kept at set values using nitric acid and ammonium hydroxide.

\subsection{Metal speciation}

Copper speciation diagrams were simulated using Hydra and Medusa softwares ${ }^{15}$ to identify the different species in solution. Speciation was investigated considering the used stoichiometric ratio of copper salt.

\subsection{Clay characterization}

The chemical composition of raw and calcined samples of Bofe and VL clays were obtained by X-ray fluorescence analysis, using samples fused in borate matrix.

Thermogravimetric analysis was carried out on a Micromeritics TGA in $\mathrm{N}_{2}$ atmosphere $(50 \mathrm{~mL} / \mathrm{min})$ at a heating rate of $10{ }^{\circ} \mathrm{C} / \mathrm{min}$. The samples were putted in platinum pans and scanned from room temperature to $1000{ }^{\circ} \mathrm{C}$.

The surface area was obtained by $\mathrm{N}_{2}$ physisorption at $77 \mathrm{~K}$ using the BET method.

The Cation Exchange Capacity (CEC) was determined in triplicate for raw and calcined samples of Bofe and VL clays. The ions concentration of $\mathrm{Na}^{+}$displaced by the $\mathrm{NH}_{4} \mathrm{OH}$ exchange solutions were measured by Atomic Absorption and expressed in meq $(100 \mathrm{~g})^{-1}$ of solid according to Equation 1:

$$
\mathrm{CEC}=\frac{C_{\mathrm{Na}^{+}} \cdot V_{\mathrm{NH}_{4}{ }^{+}}}{10 \cdot m \cdot f}
$$

The zero-point load of solid elements in suspension $\left(\mathrm{pH}_{\mathrm{zpc}}\right)$ was obtained using the potentiometrical titration methodology ${ }^{16}$. The titration was carried out with $0.5 \mathrm{M}$ $\mathrm{CH} 3 \mathrm{COOH}$ and $0.5 \mathrm{M} \mathrm{NH} 4 \mathrm{OH}$. For each point of the titration, was obtained by Equation 2:

$$
S=\frac{C_{a}-C_{b}+\left[O H^{-}\right]-\left[H^{+}\right]}{A \cdot C_{m}} \cdot F
$$

For $\mathrm{CH}_{3} \mathrm{COOH}$ or $\mathrm{NH}_{4} \mathrm{OH}$ addition, $S$ can be expressed as either by Equations 3 and 4:

$$
\begin{aligned}
& S=\frac{C_{a}-\left[H^{+}\right]}{A \cdot C_{m}} \cdot F \\
& S=\frac{\left[O H^{-}\right]-C_{b}}{A \cdot C_{m}} \cdot F
\end{aligned}
$$

\subsection{Batch sorption procedure}

The adsorption experiments were performed using an aqueous solution of $\mathrm{Cu}\left(\mathrm{NO}_{3}\right)_{2} \cdot 3 \mathrm{H}_{2} \mathrm{O}$ in fixed concentrations, with temperature controlled under constant stirring of $150 \mathrm{rpm}$. At specific time intervals, solution aliquots were removed and centrifuged. The supernatant liquid was diluted and it concentration was determined by atomic absorption spectrometry.

To evaluate the effect of contact time, the experiments were conducted using $1 \mathrm{~g}$ of clay per $100 \mathrm{~mL}$ of copper solution at $1.57 \mathrm{mmol} . \mathrm{L}^{-1}$ concentration. Temperature and $\mathrm{pH}$ were kept at $298 \mathrm{~K}$ and 5.0, respectively. The samples were shaken for 300 minutes.

Equilibrium tests were performed with different concentrations of adsorbate and temperatures. For maintaining $\mathrm{pH}$ of the medium, solutions of $0.01 \mathrm{M} \mathrm{HNO}_{3}$ or $0.01 \mathrm{M} \mathrm{NH}_{4}(\mathrm{OH})$ were added to adjust the $\mathrm{pH}$ value. The $\mathrm{pH}$ was monitored before and after adsorption. The following conditions were maintained for the different sets of experiments:

i) Effects of adsorbate concentration and adsorption isotherm: clay $1 \mathrm{~g} / 100 \mathrm{~mL}$.

ii) Thermodynamics: clay $1 \mathrm{~g} / 100 \mathrm{~mL}$, time 300 minutes, pH 5.0, temperature 273, 298, 323 and $348 \mathrm{~K}$.

Langmuir's theoretical model ${ }^{17}$ (Equation 5) and Freundlich's empirical model ${ }^{18}$ (Equation 6) were adjusted to the adsorption isotherms.

$$
q_{e q}=\frac{q_{m} \cdot b \cdot C_{e q}}{1+b \cdot C_{e q}}
$$

$q_{e q}=\left(K_{f} \cdot C_{e q}\right)^{n}$

The adsorbed amount was obtained by Equation 7:

$q=\frac{V\left(C_{i}-C_{f}\right)}{m}$

The essential characteristics of the Langmuir isotherm can be expressed by the separation factor or equilibrium parameter $(R L)$ given by Equation 8:

$$
R_{L}=\frac{1}{1+b \cdot C_{0}}
$$

The parameter $R L$ indicates the curvature of the sorption isotherm: if $R L>1$, the isotherm is not favorable; if $R L=1$, linear behavior; $0<R L<1$, favorable; $R L=0$, irreversible.

The thermodynamic parameters for the adsorption process $\Delta \mathrm{H}\left(\mathrm{kJ} . \mathrm{mol}^{-1}\right), \Delta \mathrm{S}\left(\mathrm{J}(\mathrm{K} . \mathrm{mol})^{-1}\right)$ and $\Delta \mathrm{G}\left(\mathrm{kJ} . \mathrm{mol}^{-1}\right)$ were evaluated using thermodynamic Equations 9 and 10:

$\Delta G=-R T \ln \left(K_{d}\right)$

$\ln \left(K_{d}\right)=-\frac{\Delta G}{R T}=\frac{\Delta S}{R}-\frac{\Delta H}{R T}$

The $\ln (K d)$ vs. $1 / T$ graph must be linear with inclination of the straight line $(-\Delta H / R)$ and intercept the $\mathrm{y}$ axis at $(\Delta S / R)$, providing the values for $\Delta H$ and $\Delta S$. The variation in Gibbs free energy $(\Delta G)$ is the fundamental criterion of the process spontaneity. 
Table 1. Chemical clay for Bofe and VL analyses.

\begin{tabular}{lcccccccccccc}
\hline \multirow{1}{*}{ Sample } & \multicolumn{10}{c}{ Composition (\%) } \\
\cline { 2 - 12 } & $\mathbf{L O I} *$ & $\mathbf{S i O}_{2}$ & $\mathbf{A l}_{2} \mathbf{O}_{\mathbf{3}}$ & $\mathbf{T i O}_{\mathbf{2}}$ & $\mathbf{F e}_{\mathbf{2}} \mathbf{O}_{\mathbf{3}}$ & $\mathbf{C a O}$ & $\mathbf{M g O}$ & $\mathbf{N a}_{\mathbf{2}} \mathbf{O}$ & $\mathbf{K}_{\mathbf{2}} \mathbf{O}$ & $\mathbf{M n O}$ & $\mathbf{P}_{\mathbf{2}} \mathbf{O}_{\mathbf{5}}$ & $\mathbf{T o t a l}$ \\
\hline Raw bofe & 7.09 & 70.10 & 13.64 & 0.63 & 5.44 & 0.31 & 2.08 & 0.58 & 0.16 & 0.01 & 0.03 & 100.06 \\
Calcined bofe & 3.77 & 69.03 & 14.28 & 0.57 & 6.94 & 0.46 & 4.50 & 0.24 & 0.15 & 0.01 & 0.04 & 100.00 \\
Raw VL & 8.72 & 54.29 & 19.71 & 1.30 & 9.27 & 0.76 & 3.30 & 0.64 & 1.94 & 0.03 & 0.06 & 100.01 \\
Calcined VL & 4.38 & 54.13 & 19.36 & 0.93 & 15.14 & 0.48 & 4.13 & 0.27 & 1.08 & 0.05 & 0.05 & 99.99 \\
\hline
\end{tabular}

*Loss on ignition.

\subsection{Column sorption procedure}

Adsorption experiments were performed in a porous bed system, consisting of an acrylic column, with $14 \mathrm{~cm}$ of height and $1.4 \mathrm{~cm}$ of internal diameter. The operating conditions were based on the experimental design, considering the study conducted in batch and preliminary fixed-bed tests.

In order to determine the mass transfer zone, the amount of useful and total removal were calculated, which correspond to the capacity of metal removal until the breakthrough point $(q U)$ and saturation point $(q T)$, respectively. Equations 11 and 12 were obtained through the mass balance in the column using saturation data, based on its breakthrough curves, where the area below the curve $(1-C / C O)$ until the breakthrough point is proportional to $q U$, and area until the bed exhaustion is proportional to $q T$ :

$q_{U}=\frac{C_{0} \cdot Q}{1000 \cdot m} \int_{0}^{t_{b}}\left(1-\frac{\left.C\right|_{z=L}}{C_{0}}\right) d t$

$q_{T}=\frac{C_{0} \cdot Q}{1000 \cdot m} \int_{0}^{t_{\text {tot }}}\left(1-\frac{\left.C\right|_{z=L}}{C_{0}}\right) d t$

MTZ can then be calculated based on the $q U / q T$ ratio according to Equation 13.

$M T Z=H_{L} \cdot\left(1-\frac{q_{U}}{q_{T}}\right)$

MTZ has a maximum value which corresponds to the bed height $(H L)$ and when the efficacy of mass transference increases. This value decreases until reaching the ideal condition, where MTZ is zero and the breakthrough curve is a step function.

The percentage of total removal (\%RT) during adsorption was obtained considering the metal fraction in solution retained in the adsorbent solid, from total effluent used in the adsorption process until bed saturation. The amount of adsorbed metal is calculated by considering the area of the curve $(1-C / C O)$ vs. $t^{19}$ using Origin version 6.0 software.

\section{Results and Discussion}

\subsection{Bofe and VL clays characterization}

The chemical composition of the compounds raw and calcined of the Bofe and VL clays obtained by XRF are shown in Table 1. The average composition is consistent with the expected for this bentonite clay ${ }^{20}$. One can observe
Table 2. Cationic clay exchange capacity (CEC) and surface area.

\begin{tabular}{lcc}
\hline \multicolumn{1}{c}{ Sample } & $\begin{array}{c}\text { CEC } \\
\left(\mathbf{m e q}(\mathbf{1 0 0} \mathbf{~ g})^{-1}\right)\end{array}$ & $\begin{array}{c}\text { Surface area } \\
\left(\mathbf{m}^{\mathbf{2}} \cdot \mathbf{g}^{-1}\right)\end{array}$ \\
\hline Raw Bofe & $93.33 \pm 5.74$ & $78.61 \pm 1.14$ \\
Calcined Bofe & $55.65 \pm 4.26$ & $90.31 \pm 3.65$ \\
Raw Verde-lodo & $87.54 \pm 2.46$ & $64.31 \pm 3.13$ \\
Calcined Verde-lodo & $47.83 \pm 2.46$ & $62.08 \pm 0.52$ \\
\hline
\end{tabular}

that the Bofe and VL clays are a polycationic bentonite due to the presence of $\mathrm{Ca}^{2+}, \mathrm{Mg}^{2+}$ and $\mathrm{Na}^{+}$cations in both raw and calcined clay samples.

Cationic capacity result exchanges (CEC) of raw and calcined clays and superficial respective areas obtained by BET are shown in the Table 2.

Smectite clays from Paraíba generally present CEC values between 50 e $90 \mathrm{meq}(100 \mathrm{~g})^{-1}$ of clay ${ }^{20}$. Relatively high CEC values of raw clays indicated that they have a high isomorphic replacement level. On the other hand, calcined smectites at $500{ }^{\circ} \mathrm{C}$ have their exchange cation capacity drastically reduced in comparation to raw CEC clays. The high value of CEC with respect to the raw clays indicates that the minerals have a high level of isomorphic substitutions. In addition, the smectite calcined at $500{ }^{\circ} \mathrm{C}$ has a lower ability to exchange cations in relation to the raw clay.

The values obtained to surface area by the BET method for raw and calcined Bofe clays were of 78.61 and $90.31 \mathrm{~m}^{2} \cdot \mathrm{g}^{-1}$, respectively, whereas for samples of VL clays the values were of 64.31 and $62.08 \mathrm{~m}^{2} . \mathrm{g}^{-1}$, in the same order.

Figure 1 shows TG and DTG curves for raw Bofe and VL clays. The DTG curve presents two peaks of mass loss. The first, between $50-105^{\circ} \mathrm{C}$ refers to the loss of water, volatile compounds, microorganisms and organic material; these elements do not change clay structure. Mass losses occurred for two temperatures and correspond to 4.82 and $3.57 \%$ of mass. The second peak occurring between $450-500{ }^{\circ} \mathrm{C}$ shows the loss of hydroxyl, which starts to change the clay structure. Hydroxyl loss is interesting for the process, because it prevents the chemical precipitation of copper by alkalinity and it increases the clay stability for its application in fixed-bed adsorption columns.

According to Figure 2, the $\mathrm{pH}_{\mathrm{ZPC}}$ values obtained for raw and calcined clays were of 6.1 and 5.4, respectively. Thus, in order to ensure that the calcined clay surface has a null or negative charge with the aim of making more favorable the adsorption of charged positively metal ions, the adsorbate solution $\mathrm{pH}$ should be kept in 5.5. 


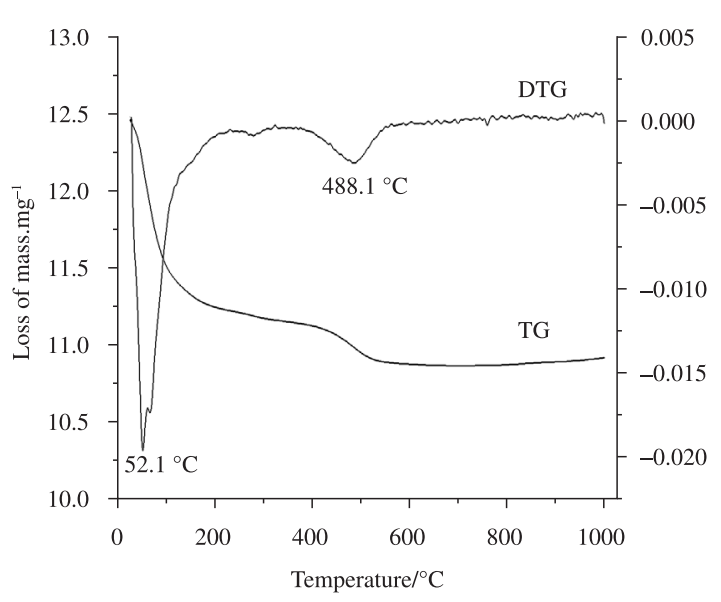

(a)

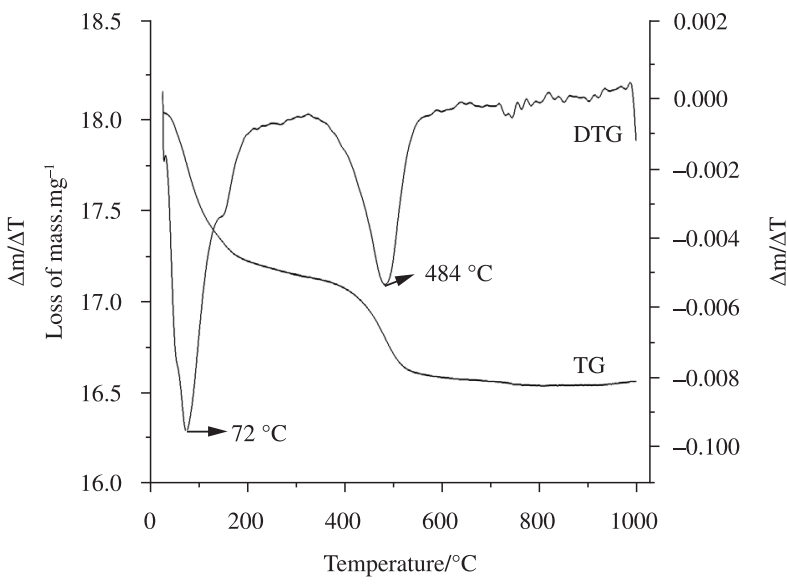

(b)

Figure 1. TG and DTG curves of raw: a) Bofe; and b) VL clays.

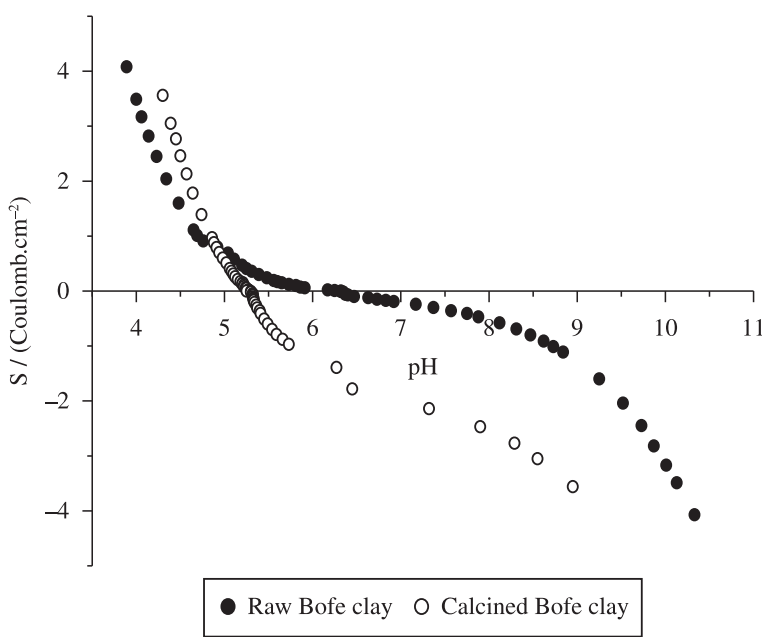

(a)

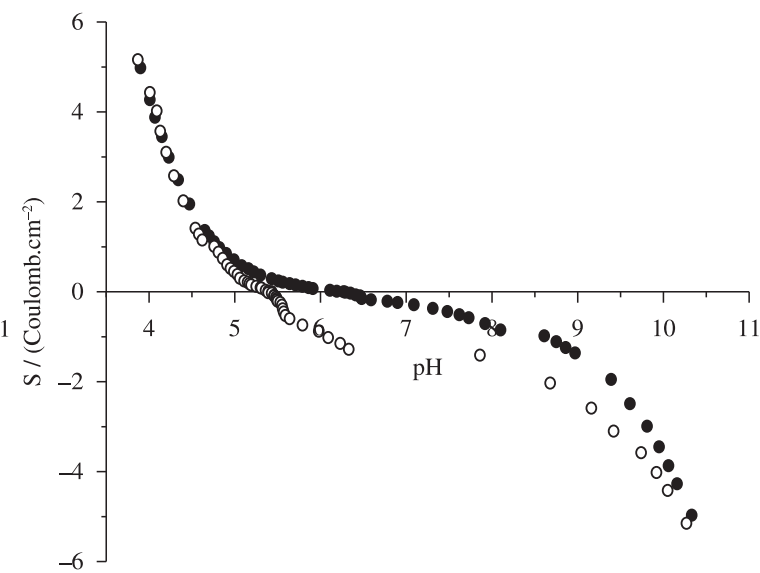

Raw VL claynatural O Calcined VL clay

(b)

Figure 2. Charge density (Coulomb $\mathrm{cm}^{-2}$ ) vs. $\mathrm{pH}$ curves of: a) Bofe, and b) VL clay samples.

\subsection{Copper speciation}

The Figure 3 shows the speciation curve of the $\mathrm{Cu}^{2+}$ ion in aqueous solution with nitrate ions at different concentrations determined through the HYDRA application. In the $\mathrm{pH}$ range of 4.8-5.3, the fraction of $\mathrm{Cu}^{2+}$ ions in aqueous solution decreases and beginning the formation of copper oxide, which is precipitates. With the purpose that only the adsorption occurs, should be used a $\mathrm{pH}$ value below minimum precipitation, which corresponds to 5.0 for concentration of $1.57 \mathrm{mmol} . \mathrm{L}^{-1}$.

\subsection{Batch adsorption}

Figure $4 \mathrm{a}$ and $\mathrm{b}$ present the curve for copper adsorption kinetics on Bofe and VL clays. The adsorption of copper ions into pores of clays occurred rapidly at the first moments of the process, remaining at equilibrium over time. The reduction of the initial concentration of the ion, under the condition of this study, was around $81 \%$ in both raw clays and around $42 \%$ in both calcined clays. The maximum adsorbed amount was around 0.13 and $0.08 \mathrm{mmol}$ of copper $\mathrm{g}^{-1}$ of clay for raw and calcined clays, respectively.

Through kinetic studies at static system, it is verified that removal capacity is reduced by clay calcinations. However, in preliminary tests, raw clays could not be applied in fixed bed due to their mechanical instability. When the raw clays were in contact with copper salt solutions, the clay adsorbed a great quantity of water, expanding the volume bed due to their blade defoliation, which are dissolved and dispersed along the flow, being the clay dragged down through the column when the flow is ascendant. At a descendent flow use, a bed waterproofing was also observed.

On the other hand, clays also get steel hardness at temperatures above $180{ }^{\circ} \mathrm{C}^{20}$. This fact, associated with Bofe $^{13}$ and VL clay characterization results, suggest that the calcination provides to the materials mechanical stabilization (not dissolving), getting that these do not expand or being waterproof in porous column. Therefore, the calcined Bofe and VL clays are more appropriated to be used as adsorbent for copper removal in fixed bed. 

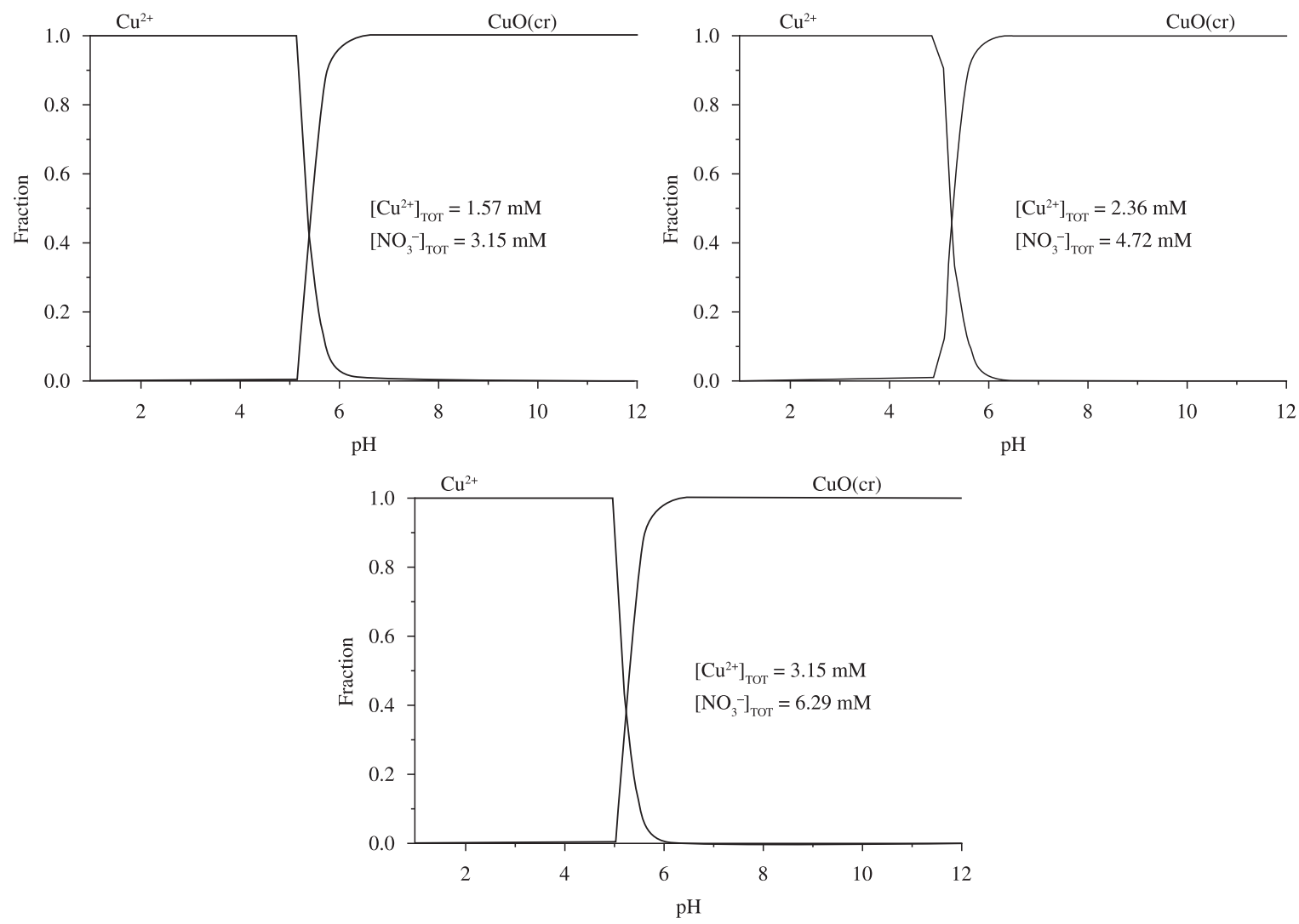

Figure 3. Copper speciation.

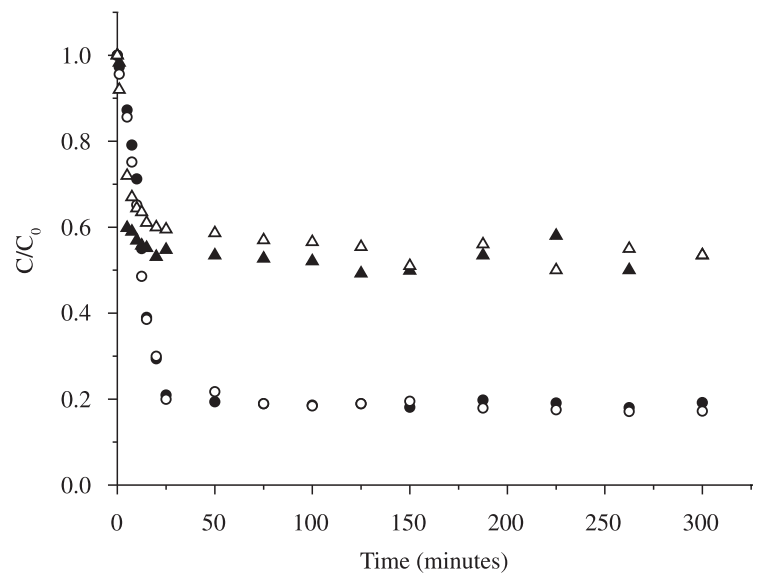

(a)

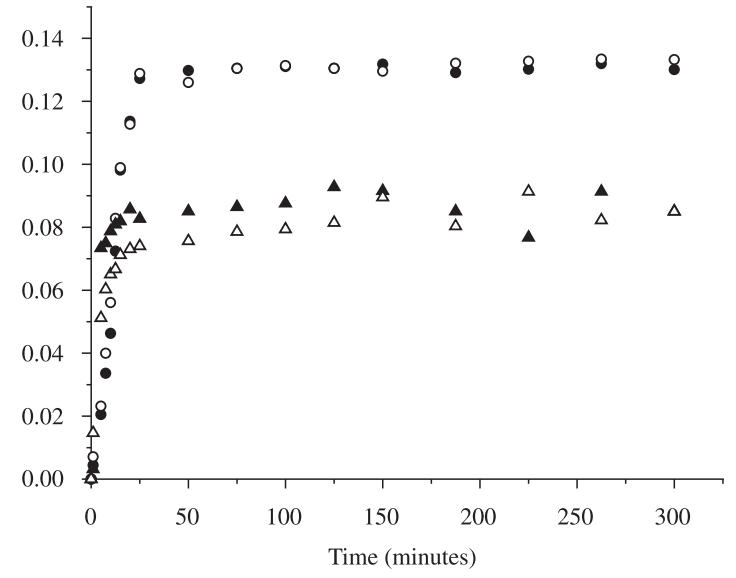

(b)

- Raw Bofe clay $O$ Raw VL clay $\Delta$ Calcined Bofe clay $\Delta$ Calcined VL clay

Figure 4. Kinetic for copper adsorption on clays. a) Dimensionless solution concentration as a function of time, and b) Adsorbed amount at equilibrium $\left(\mathrm{C}_{0}=1.57 \mathrm{mmol} \mathrm{L}^{-1}, \mathrm{~d}_{\mathrm{p}}=0.855 \mathrm{~mm}\right)$.

\subsection{Dynamic adsorption}

Dynamic adsorption experiments were carried out for different flow rates, varying values from 2.0 to $6.0 \mathrm{~mL} / \mathrm{min}$ for Bofe and from 2.0 to $5.0 \mathrm{~mL} / \mathrm{min}$ for VL clay (Figure 5). The definition of appropriate flow rate was based on mass transfer zone determination. The concentration values of copper adsorbate solution were 2.36 and 1.57 mmol.L $\mathrm{L}^{-1}$ for adsorption on Bofe and VL clays, respectively. The breakthrough curves present distinct behaviors indicating the flow influence on diffusional resistances. The adsorption process presents strong resistance to bed saturation for the 


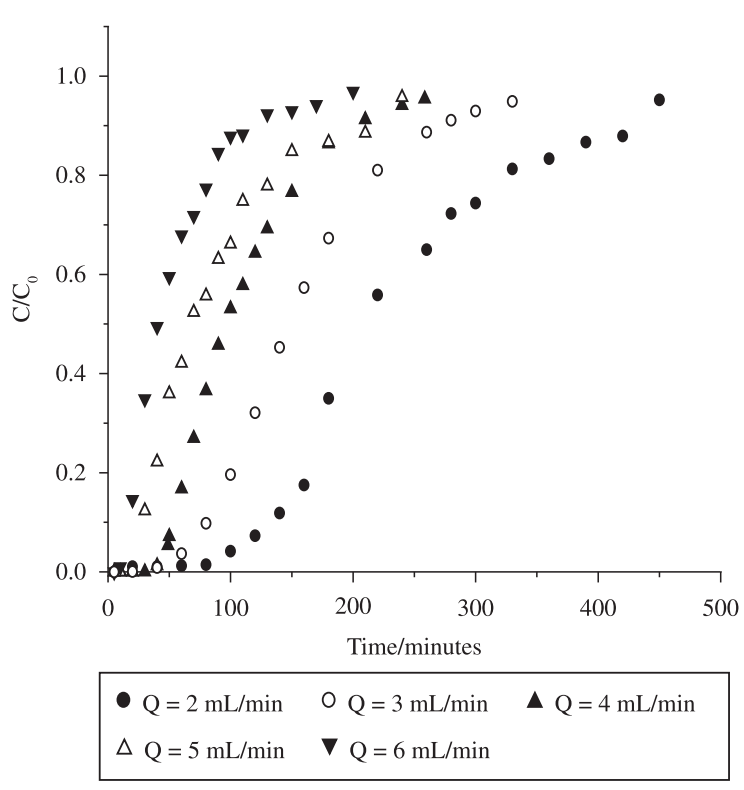

(a)

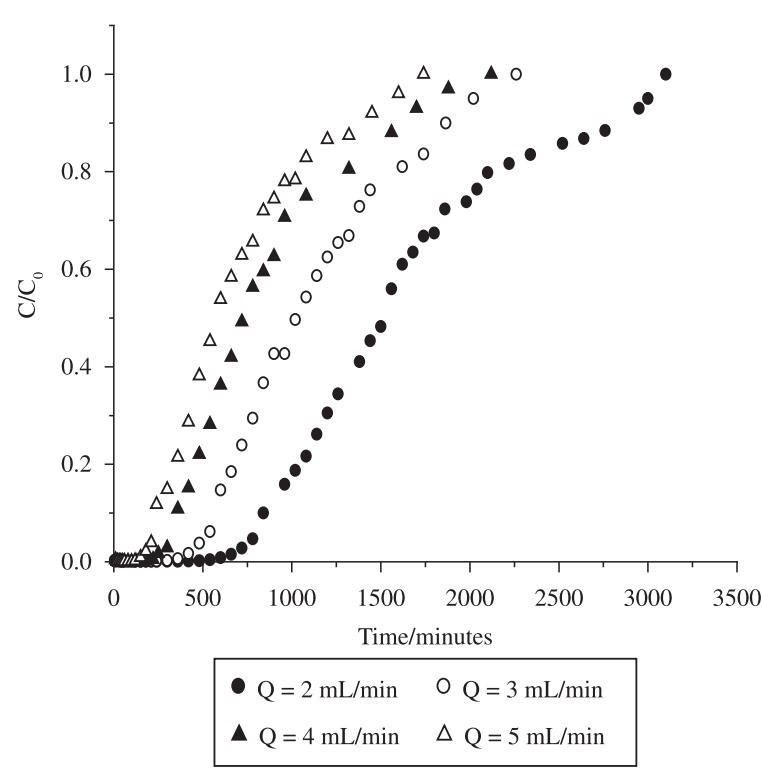

(b)

Figure 5. Breakthrough curves for: a) $\mathrm{Cu}^{2+} / \mathrm{Bofe}$ calcined clay $\left(\mathrm{C}_{0}=2.36 \mathrm{mmol} \cdot \mathrm{L}^{-1}, \mathrm{~d}_{\mathrm{p}}=0.855 \mathrm{~mm}\right)$, and b) $\mathrm{Cu}^{2+} / \mathrm{VL}$ calcined clay $\left(\mathrm{C}_{0}=1.57 \mathrm{mmol} . \mathrm{L}^{-1}, \mathrm{~d}_{\mathrm{p}}=0.855 \mathrm{~mm}\right)$.

total flow range studied, it was known by the more extended breakthrough curves and broader mass transfer zones.

Table 3 shows the values of MTZ, $q U, q T$ and copper removal percentage on calcined clays. The least MTZ value $(7.77 \mathrm{~cm})$, as well as satisfactory values of amount of useful $(q U)$ and total removal $(q T)$ and total removal percentage was obtained at $4.0 \mathrm{~mL} / \mathrm{min}$ for copper adsorption on calcined Bofe clay. For copper adsorption on calcined VL clay, the least $M T Z$ value $(7.35 \mathrm{~cm})$ was obtained at $2.0 \mathrm{~mL} / \mathrm{min}$, but the breakthrough curve showed high resistance of saturation. Then, the most appropriate flow value for conducting the copper adsorption on calcined VL clay assays was $3.0 \mathrm{~mL} / \mathrm{min}$.

The reproducibility of adsorption experiments can be seen in Figure 6, which shows breakthrough curves resulting from three performed tests at 4.0 and $3.0 \mathrm{~mL} / \mathrm{min}$ for copper removal on calcined Bofe and VL clays, respectively. These results confirms the good reproducibility of the experimental, with a 0.34 and $0.33 \%$ average deviation for copper adsorption on calcined clays Bofe and VL, respectively. The variation curves are basically due to the axial bed dispersion and this phenomenon was not considered in the study.

\subsection{Adsorption isotherms}

The amount adsorbed of metal ions per mass unit of clay $\left(q_{e q}\right)$ gradually increases as the initial concentration of the adsorbate solution increases, in both systems (batch and fixed bed). When the initial solution has a low concentration, the ratio between the number of ions and the number of adsorptive sites available is small; consequently, adsorption depends on the initial concentration. Therefore, as the concentration of ions increases, adsorption also increases. In high concentrations of ion, each unit mass of adsorbent is subjected to a larger number of ions, which depending on
Table 3. Values for $M T Z, q U, q T$ and \% RT for copper adsorption on calcined Bofe and VL clays.

\begin{tabular}{lccccc}
\hline \multicolumn{1}{c}{ System } & $\begin{array}{c}\text { Outflow } \\
(\mathbf{m L / m i n})\end{array}$ & $\begin{array}{c}\boldsymbol{M T Z} \\
(\mathbf{c m})\end{array}$ & $\begin{array}{c}\boldsymbol{q} \boldsymbol{U} \\
\left(\mathbf{m m o l . g} \mathbf{- 1}^{-1}\right)\end{array}$ & $\begin{array}{c}\boldsymbol{q} \boldsymbol{T} \\
\left(\mathbf{m m o l . g} \mathbf{-}^{-1}\right)\end{array}$ & $\boldsymbol{\%} \mathbf{R T}$ \\
\hline Cu/calcined & 2 & 7.81 & 0.0422 & 0.1056 & 52.10 \\
Bofe clay & 3 & 8.1 & 0.0417 & 0.1106 & 34.71 \\
& 4 & 7.77 & 0.0396 & 0.0985 & 41.86 \\
& 5 & 10.04 & 0.0228 & 0.1006 & 35.48 \\
& 6 & 10.98 & 0.0114 & 0.0732 & 25.83 \\
\hline Cu/calcined & 2 & 7.35 & 0.0784 & 0.1648 & 49.82 \\
VL clay & 3 & 7.66 & 0.0796 & 0.1761 & 55.26 \\
& 4 & 8.81 & 0.067 & 0.1808 & 40.02 \\
& 5 & 9.98 & 0.048 & 0.167 & 49.70 \\
\hline
\end{tabular}

the system can present different behaviors, as can be seen in Figure 7. The Langmuir and Freundlich models were adjusted to experimental data through the Gauss-Newton nonlinear estimation method in the Statistic 7.0 for Windows $^{\circledR}$ software. The regression coefficients for both adjustments are shown in Table 4 . The obtained parameters expressed by Equations 6 and 7 were associated with the process temperature.

Analyzing Figure 7 and Table 4, it can be seen that Langmuir model simulated adequately the experimental adsorption isotherm data for Bofe clay in batch and for VL clay in fixed bed system, while Freundlich empiric model described more efficiently the adsorption isotherm data for Bofe clay in fixed bed and for VL clay in batch system.

From the adsorption isotherms data, the maximum adsorbed capacities obtained in fixed bed system for both clays is higher than the results got in batch, which means that copper adsorption on Bofe and VL clays is related to 


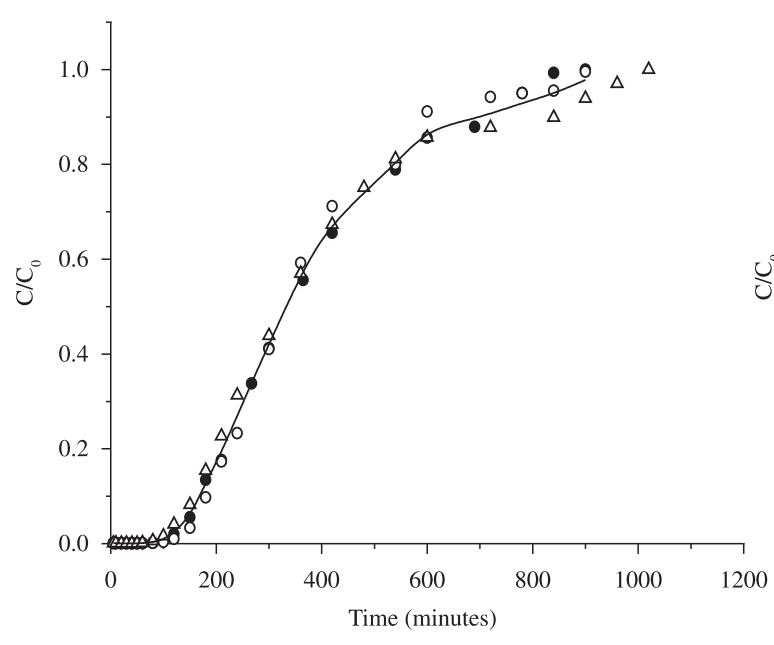

(a)

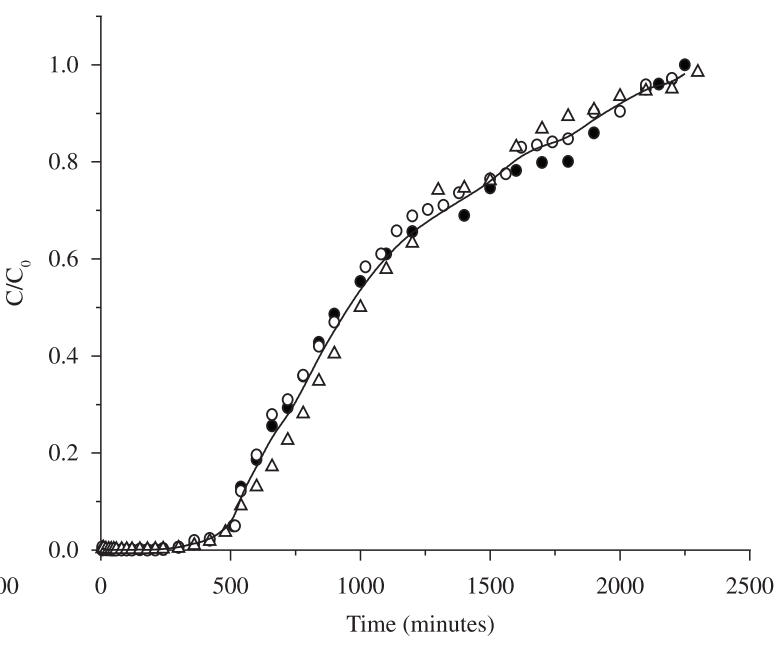

(b)

- Breakthrough 1 O Breakthrough $2 \Delta$ Breakthrough $3-$ Average of breakthrough

Figure 6. Reproducibility of breakthrough curves for copper adsorption on calcined clays: a) Bofe, and b) VL $\left(\mathrm{C}_{0}=1.57 \mathrm{mmol} . \mathrm{L}^{-1}\right.$, $\left.\mathrm{d}_{\mathrm{p}}=0.855 \mathrm{~mm}\right)$.

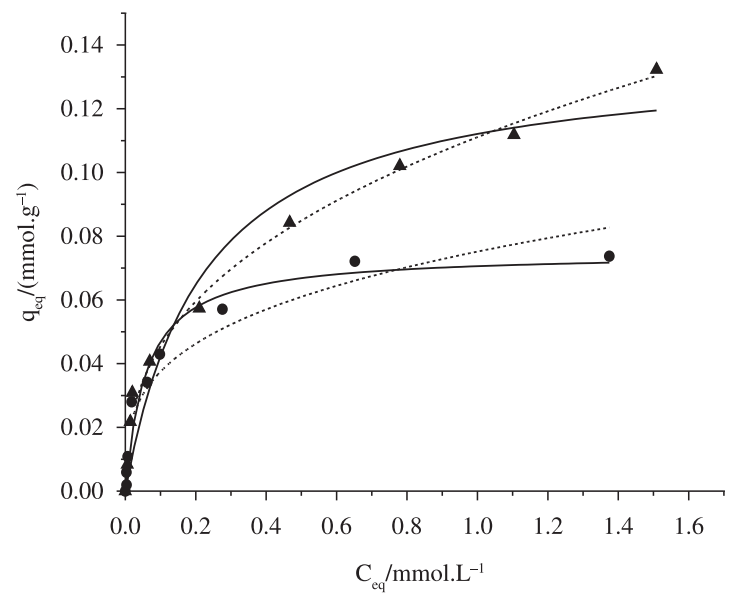

(a)

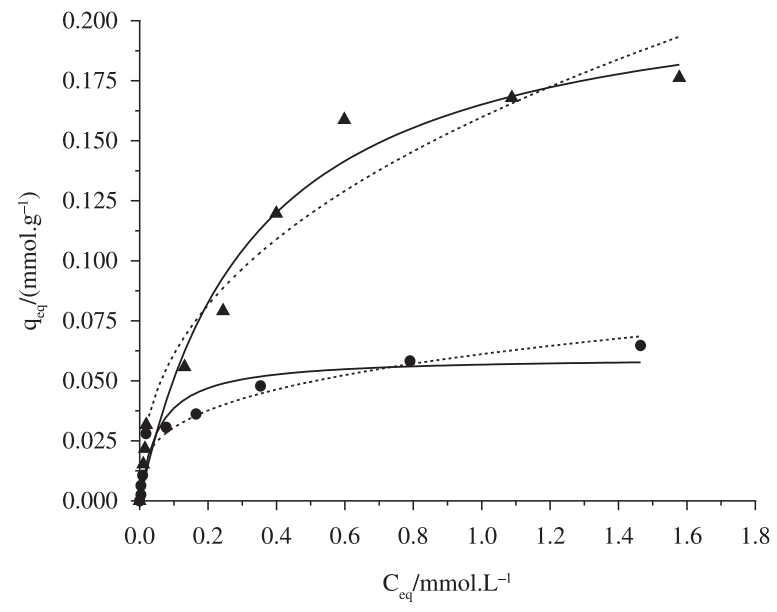

(b)

Batch $\Delta$ Fixed bed Langmuir …........ Freundlich

Figure 7. Adsorption isotherms for copper removal on: a) calcined Bofe clay, and b) calcined VL clay, adjusted to the models Langmuir and Freudlich.

Table 4. Langmuir and Freundlich parameters for $\mathrm{Cu}^{2+}$ adsorption on Bofe and VL clays.

\begin{tabular}{|c|c|c|c|c|c|c|}
\hline \multirow[t]{2}{*}{ System } & \multicolumn{3}{|c|}{ Langmuir } & \multicolumn{3}{|c|}{ Freundlich } \\
\hline & $q m\left(\mathrm{mmol} \mathrm{g}^{-1}\right)$ & $b\left(\mathbf{L} . g^{-1}\right)$ & $\mathbf{R}^{2}$ & $a$ & $n$ & $\mathbf{R}^{2}$ \\
\hline $\mathrm{Cu} /$ calcined Bofe/batch & 0.0748 & 16.7868 & 0.9725 & 0.0752 & 0.3015 & 0.9259 \\
\hline $\mathrm{Cu} /$ calcined Bofe/fixed bed & 0.1371 & 4.4815 & 0.9478 & 0.1111 & 0.3877 & 0.922 \\
\hline $\mathrm{Cu} /$ calcined VL/batch & 0.0599 & 18.198 & 0.9288 & 0.0611 & 0.3009 & 0.9378 \\
\hline $\mathrm{Cu} /$ calcined VL/fixed bed & 0.22 & 3.0089 & 0.9718 & 0.1598 & 0.4175 & 0.951 \\
\hline
\end{tabular}


the mobility of the particles. This behavior indicates that at higher concentrations of metal solution in batch occurred a formation of the electrical double layer, i. e., ions of the Stern layer and part of the diffuse layer. They form an ionic cloud around the particle, being attracted by the electric potential, which moves along with it during the flow of the suspension $^{21}$. As a result, the particles start to behave as flow units of higher dimensions, whose radius is defined as the hydrodynamic radius of the particle, which decreases the maximum adsorbed capacity of copper on calcined clays. However, this behavior is not observed in Henry's infinite dilution region, that is, at very low concentrations.

The Langmuir isotherm is specific for monolayer adsorption, which was the case in this study, while the Freundlich model is better applied to adsorption at heterogeneous sites on the surface of a solid, with a mechanism that has not yet been established. The Langmuir equilibrium coefficient $b$ determines the direction to which the equilibrium adsorbate-adsorbent clay (solid phase) + $\mathrm{Cu}$ (II) (aqueous phase) $=$ clay $-\mathrm{Cu}$ (II) moves. Higher values indicate that the equilibrium moves to the right side, with the resulting formation of the adsorbate-adsorbent complex.

The values obtained for the Freundlich constant $(n)$ are around 0.3 and 0.4 for adsorption in batch and in fixed bed, respectively. According to Treybal, ${ }^{22}$ this range indicates that the adsorptive characteristics of the clay are suitable for copper sorption.

The values calculated for $R L$ (Equation 8) determined by using the Langmuir constant obtained by the nonlinear method vs. the initial copper concentration for different systems were of 0.3076 (Cu/calcined Bofe/Batch), 0.6995 (Cu/calcined Bofe/fixed bed), 0.2907 (Cu/calcined VL/ Batch) and $0.7682(\mathrm{Cu} /$ calcined VL/fixed bed). According to the separation values, both adsorption systems can be considered favorable to copper sorption $(0<R L<1)$, being more favorable to sorption conducted in batch.

\subsection{Adsorption thermodynamics}

Thermodynamic data were obtained through the static method in thermostatic finite bath under constant stirring for four different temperatures $(273,298,323$ and $348 \mathrm{~K})$ and correlated by the Langmuir and Freundlich isotherms. The Figure 8 shows the adsorption isotherms for $1 \mathrm{~g}$ clay/100 mL adsorbate solution adjusted by the Langmuir and Freundlich models, at initial copper concentrations ranging from 0.08 to 2.36 mmol. $\mathrm{L}^{-1}$.

The thermodynamic parameters $\Delta \mathrm{H}, \Delta \mathrm{S}$ and $\Delta \mathrm{G}$ (Equations 9 and 10) presented in Table 5 were obtained from Figure 9. The negative $\Delta \mathrm{H}$ indicates that the process is exothermal, confirming the adsorption theory for copper adsorption on calcined VL clay. The magnitude of the

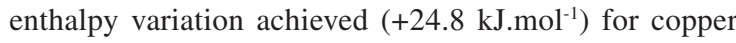
adsorption on calcined Bofe clay showed that it is an endothermic processes.

A decrease in entropy during adsorption helps the stabilization of the metal-clay complex formed $(\Delta \mathrm{S}<0)$. $\Delta S$ values suggest a decrease in randomness at the solid/ solution interface during copper sorption on calcined VL

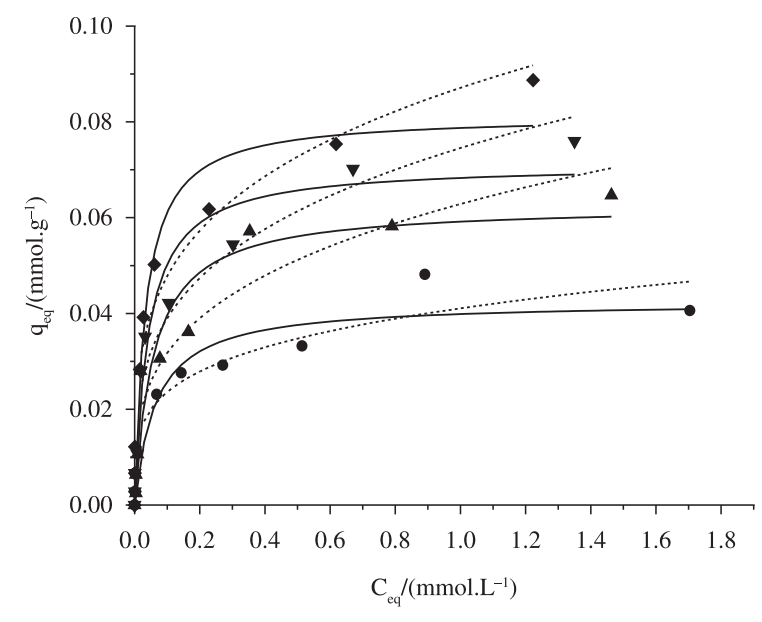

(b)

ch

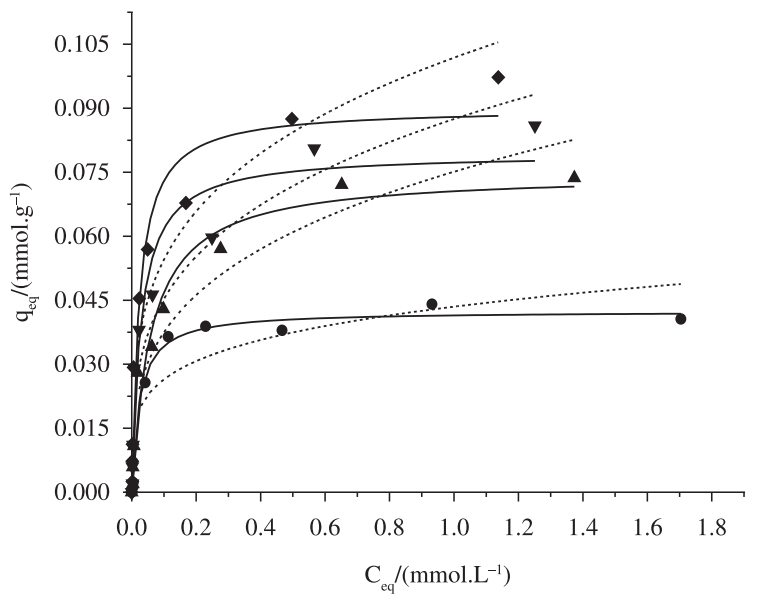

(a)

Figure 8. Adsorption isotherms for copper removal on: a) calcined Bofe clay, and b) calcined VL clay in different temperatures.

Table 5. Thermodynamic parameters of adsorption.

\begin{tabular}{|c|c|c|c|c|c|c|}
\hline \multirow[t]{2}{*}{ System } & \multirow{2}{*}{$\begin{array}{c}\Delta H \\
\left(\mathbf{k J} . \mathrm{mol}^{-\mathbf{1}}\right)\end{array}$} & \multirow{2}{*}{$\begin{array}{c}\Delta S \\
\left(\mathbf{J}(\mathbf{m o l} \cdot \mathbf{K})^{-1}\right)\end{array}$} & \multicolumn{4}{|c|}{$\Delta G\left(\mathbf{k J} . \mathrm{mol}^{-1}\right)$} \\
\hline & & & $273 \mathrm{~K}$ & $\mathbf{T}_{\text {room }}$ & $323 \mathrm{~K}$ & $348 \mathrm{~K}$ \\
\hline $\mathrm{Cu} /$ calcined Bofe & +24.8 & +151.5 & -16.6 & -20.3 & -24.1 & -27.9 \\
\hline $\mathrm{Cu} /$ calcined VL & -4.81 & +53.7 & -19.5 & -20.8 & -22.2 & -23.5 \\
\hline
\end{tabular}

$\mathrm{T}_{\text {room }}: 298 \mathrm{~K}$ for Cu/calcined Bofe and $297 \mathrm{~K} \mathrm{Cu} /$ calcined VL clays. 
Table 6. Thermodynamic parameters data for $\mathrm{Cu}(\mathrm{II})$ in different clays.

\begin{tabular}{lccc}
\hline \multicolumn{1}{c}{ Clay } & $\Delta \boldsymbol{H}\left(\mathbf{k J . \mathbf { m o l } ^ { - 1 } )}\right.$ & $\Delta \boldsymbol{S}\left(\mathbf{J}(\mathbf{m o l} . \mathbf{K})^{-\mathbf{1}}\right)$ & Reference \\
\hline Acid activated montmorillonite & +45.7 & +334.5 & 23 \\
Bentonite Turkey & +10.36 & +42.0 & 24 \\
Montmorillonite (M1) & +50.7 & +180.7 & 25 \\
Spent activated clay & +14.52 & +138.9 & 26 \\
Na-montmorillonite & +18.36 & -200.5 & 27 \\
NaDS-montmorillonite & +7.1 & +9.1 & 28 \\
Calcined Bofe & +24.8 & +86.4 & Present work \\
\hline
\end{tabular}

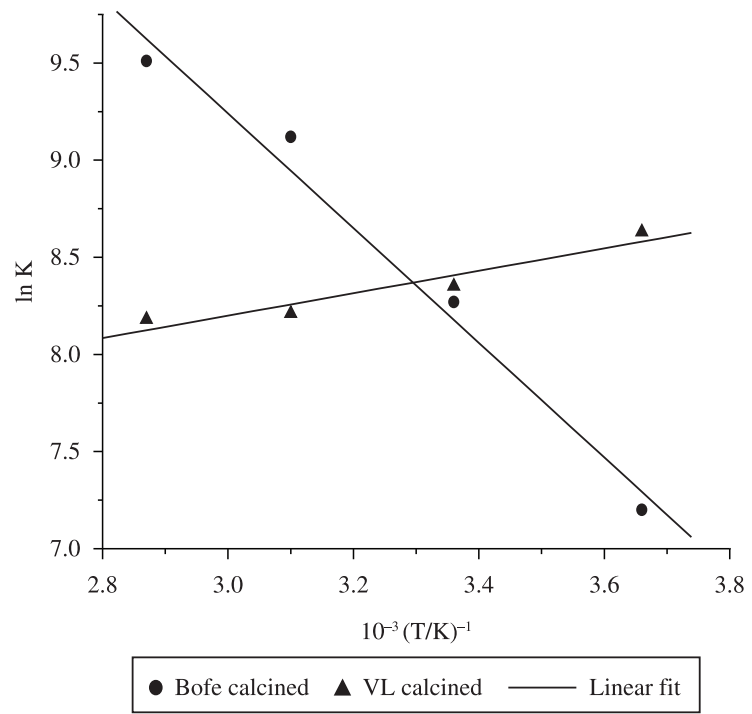

Figure 9. Adsorbate distribution coefficient as function of temperature.

clay compared with Bofe clay. The clays- $\mathrm{Cu}$ interactions occurred spontaneously and were accompanied by a decrease in Gibbs free energy $(\Delta \mathrm{G}<0)$. The degree of spontaneity was found to decline as the process temperature

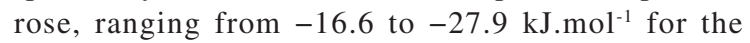
temperature range between 273 and $348 \mathrm{~K}$. Adsorption and ion exchange of $\mathrm{Cu}(\mathrm{II})$ on different clays had already been reported as endothermic ${ }^{23-28}$, as shown in Table 6. It was likely that adsorption of $\mathrm{Cu}$ (II) ions on clay surface require an activation energy and rise in temperature helped more $\mathrm{Cu}$ (II) ions to overcome this energy barrier and get attached to the surface ${ }^{23}$.

\section{References}

1. Ghorbel-Abid I, Galai K and Trabelsi-Ayadi M. Retention of chromium (III) and cadmium (II) from aqueous solution by illitic clay as a low-cost adsorbent. Desalination. 2010; 256:190-195. http://dx.doi.org/10.1016/j.desal.2009.06.079

2. Praus P, Turicováa $\mathbf{M}$ and Valáškováb $\mathrm{M}$. Study of silver adsorption on montmorillonite. Journal of the Brazilian Chemical Society. 2008; 19:549-556. http://dx.doi.org/10.1590/ S0103-50532008000300025

\section{Conclusions}

The chemical composition of clays was not modified by calcination, but the Cation Exchange Capacity (CEC) was reduced. Adsorption results indicated that the sorption kinetics of copper ions by clays is rapid, requiring a minimum 60 minutes to reach equilibrium. The study of mass transfer parameters, as well as the breakthrough curves showed that the better appropriate operating outflow rate values, i.e. which minimizes the diffusional resistances in the bed for removal of copper by Bofe and VL calcined clays were of 4 and $3 \mathrm{~mL} / \mathrm{min}$, respectively. The breakthrough curves demonstrated that increasing the outflow rate, the breaking point, the point of saturation throughput and total removal values tend to decrease. The Langmuir isotherm model correctly represents the equilibrium data obtained from experiments in bath and in fixed bed at room temperature. At low concentrations, the removal of copper has a linear equilibrium and it does not depend on the system applied (static or dynamic). Calcination produced hydroxyl loss, preventing chemical precipitation of copper by alkalinity. The adsorption capacity $(\mathrm{qm})$ increased in fixed bed, which suggests that copper adsorption on calcined Bofe and VL clays is related to the mobility of the particles. Copper adsorption on calcined VL clay is exothermic whereas on Bofe clay is endothermic. The clay- $\mathrm{Cu}$ interactions occurred spontaneously, being followed by a decrease in Gibbs free energy.

\section{Acknowledgements}

The authors acknowledge and thank the financial support received from CNPq and Foundation for Research Support of Sao Paulo State, FAPESP, for this research.

3. Sajidu SMI, Persson I, Masamba WRL and Henry EMT. Mechanisms of heavy metal sorption on alkaline clays from Tundulu in Malawi as determined by EXAFS. Journal of Hazardous Materials. 2008; 158:401-409. PMid:18329799. http://dx.doi.org/10.1016/j.jhazmat.2008.01.087

4. Novakovic T, Rozic L, Petrovic S and Rosic A. Synthesis and characterization of acid-activated Serbian smectite clays obtained by statistically designed experiments. Chemical 
Engineering Journal. 2008; 137:436-442. http://dx.doi. org/10.1016/j.cej.2007.06.003

5. Kubilay S, Gürkan R, Savran A and Sahan T. Removal of $\mathrm{Cu}(\mathrm{II}), \mathrm{Zn}(\mathrm{II})$ and $\mathrm{Co}(\mathrm{II})$ ions from aqueous solutions by adsorption onto natural bentonite. Adsorption. 2007; 13:41-51. http://dx.doi.org/10.1007/s10450-007-9003-y

6. Stathi P, Litina K, Gournis D, Giannopoulos TS and Deligiannakis Y. Physicochemical study of novel organoclays as heavy metal ion adsorbents for environmental remediation. Journal of Colloid and Interface Science. 2007; 316:298-309. PMid:17804008. http://dx.doi.org/10.1016/j.jcis.2007.07.078

7. Ouhadi VR, Yong RN and Sedighi M. Desorption response and degradation of buffering capability of bentonite, subjected to heavy metal contaminants. Engineering Geology. 2006; 85:102-110. http://dx.doi.org/10.1016/j.enggeo.2005.09.031

8. Brigatti MF, Colonna S, Malferrari D, Medici L and Poppi L. Mercury adsorption by montmorillonite and vermiculite: a combined XRD, TG-MS, and EXAFS study. Applied Clay Science. 2005; 28:1-8. http://dx.doi.org/10.1016/j. clay.2004.03.006

9. Bailey SE, Olin TJ, Bricka M and Adrian D. A review of potentially low-cost sorbents for heavy metals. Water Research. 1999; 33(11):24692479.

10. Chen WJ, Hsiao LC and Chen KKY. Metal desorption from copper(II)/nickel(II)-spiked kaolin as a soil component using plant-derived saponin biosurfactant. Process Biocheistry. 2008; 43:488-498. http://dx.doi.org/10.1016/j.procbio.2007.11.017

11. Kleinübing SJ, Vieira RS, Beppu MM, Guibal E and Silva MGC. Characterization and evaluation of copper and nickel biosorption on acidic algae Sargassum Filipendula. Materials Research. 2010; 13:541-550. http://dx.doi.org/10.1590/S151614392010000400018

12. Meneghetti E, Baroni P, Vieira RS, Silva MGC and Beppu MM. Dynamic adsorption of chromium ions onto natural and crosslinked chitosan membranes for wastewater treatment. Materials Research. 2010; 13:89-94. http://dx.doi.org/10.1590/ S1516-14392010000100018

13. Vieira MGA, Almeida Neto AF, Gimenes ML and Silva MGC. Removal of nickel on Bofe bentonite calcined clay in porous bed. Journal of Hazardous Materials. 2010; 176:109-118. PMid:20022694. http://dx.doi.org/10.1016/j. jhazmat.2009.10.128

14. Vieira MGA, Almeida Neto AF, Gimenes ML and Silva MGC. Sorption kinetics and equilibrium for the removal of nickel ions from aqueous phase on calcined Bofe bentonite clay. Journal of Hazardous Materials. 2010; 177:362-371. PMid:20042281. http://dx.doi.org/10.1016/j.jhazmat.2009.12.040

15. Puigdomenech I. Hydra and Medusa Programs. Sweden: Royal Institute of Technology; 2004.
16. Davranche M, Lacour S, Bordas F and Bollinger JC. An Easy Determination of the Surface Chemical Properties of Simple and Natural Solids. Journal of Chemical Education. 2003; 80:76-78. http://dx.doi.org/10.1021/ed080p76

17. Langmuir I. The adsorption of gases on plane surfaces of glass, mica and platinum. Journal of the American Chemical Society. 1918; 40:1361-1403. http://dx.doi.org/10.1021/ja02242a004

18. Freundlich HMF. Uber die adsorption in lasugen. Zeitschrift fur Physikalische Chemie (Leipzig). 1906; 57A:385-470.

19. Volesky B, Weber J and Park JM. Continuous-flow metal biosorption in a regenerable Sargassum column. Water Research. 2003; 37:297-306. http://dx.doi.org/10.1016/S00431354(02)00282-8

20. Santos PS. Ciência e tecnologia de argilas. São Paulo: Edgard Blücher Ltda; 1992.

21. Zeta-Meter Inc. Zeta-Potential: A Complete Course in 5 Minutes. Staunton: Zeta-Meter, Inc.; 1997.

22. Treybal RE. Mass Transfer Operations. New York: McGraw Hill; 1980.

23. Bhattacharyya KG and Gupta SS. Removal of $\mathrm{Cu}$ (II) by natural and acid-activated clays: An insight of adsorption isotherm, kinetic and thermodynamics. Desalination. 2011; 272:66-75. http://dx.doi.org/10.1016/j.desal.2011.01.001

24. Eren $\mathrm{E}$ and Asfin B. An investigation of $\mathrm{Cu}(\mathrm{II})$ adsorption by raw and acid-activated bentonite: A combined potentiometric, thermodynamic, XRD, IR, DTA study. Journal of Hazardous Materials. 2008; 151:682-691. PMid:17644249. http://dx.doi. org/10.1016/j.jhazmat.2007.06.040

25. Bhattacharyya KG and Gupta SS. Adsorptive accumulation of $\mathrm{Cd}(\mathrm{II}), \mathrm{Co}(\mathrm{II}), \mathrm{Cu}(\mathrm{II}), \mathrm{Pb}(\mathrm{II})$, and $\mathrm{Ni}(\mathrm{II})$ from water on montmorillonite: Influence of acid activation. Journal of Colloid and Interface Science. 2007; 310:411-424. PMid:17368467. http://dx.doi.org/10.1016/j.jcis.2007.01.080

26. Weng C-H, Tsai C-Z, Chu S-H and Sharma YC. Adsorption characteristics of copper(II) onto spent activated clay. Separation and Purification Technology. 2007; 54:187-197. http://dx.doi.org/10.1016/j.seppur.2006.09.009

27. Lin S-H and Juang R-S. Heavy metal removal from water by sorption using surfactant-modified montmorillonite. Journal of Hazardous Materials. 2002; 92:315-326. http://dx.doi. org/10.1016/S0304-3894(02)00026-2

28. El-Batouti M, Sadek OM and Assaad FF. Kinetics and thermodynamics studies of copper exchange on $\mathrm{Na}-$ montmorillonite clay mineral. Journal of Colloid and Interface Science. 2003; 259:223-227. http://dx.doi.org/10.1016/S00219797(02)00173-X 
Appendix 1. Abbreviations.

\begin{tabular}{|c|c|}
\hline$A$ & specific surface area $\left(\mathrm{g} \cdot \mathrm{m}^{-2}\right)$ \\
\hline$b, q_{m}$ & $\begin{array}{l}\text { are Langmuir coefficients representing the equilibrium constant for the adsorbate-adsorbent } \\
\text { equilibrium and the maximum adsorbed amount on the monolayer }\end{array}$ \\
\hline$C_{0}$ & initial concentration of the metal in the liquid phase $\left(\mathrm{mmol} . \mathrm{L}^{-1}\right)$ \\
\hline$C_{a}, C_{b}$ & concentration of acid and base added, respectively $\left(\right.$ mol. $\left.\mathrm{L}^{-1}\right)$ \\
\hline$C_{e q}\left(\mathrm{mmol} . \mathrm{L}^{-1}\right)$ and $q_{e q}\left(\mathrm{mmol} . \mathrm{g}^{-1}\right)$ & concentration of metal ions in the liquid and solid phases, respectively \\
\hline$C_{i}, C_{f}$ & the initial and final concentration of metal ion, respectively $\left(\mathrm{mmol} . \mathrm{L}^{-1}\right)$ \\
\hline$C_{m}$ & represent the solid content $\left(\mathrm{g} . \mathrm{L}^{-1}\right)$ \\
\hline $\mathrm{C}_{\mathrm{Na}}^{+}$ & ion concentration $\mathrm{Na}^{+}$measured by atomic adsorption $\left(\mathrm{mg} \cdot \mathrm{L}^{-1}\right)$ \\
\hline$V_{N H 4+}$ & volume of ammonium acetate $3 \mathrm{M}(\mathrm{mL})$ \\
\hline$f$ & conversion factor of sodium to equivalents \\
\hline$F$ & Faradays constant $\left(96,485.3399\right.$ Coulomb mol$\left.^{-1}\right)$ \\
\hline$K_{d}$ & adsorbate distribution coefficient $\left(q_{e q} / C_{e q}\right.$ em L. $\left.\mathrm{g}^{-1}\right)$ \\
\hline$K_{f}, n$ & Freundlich coefficients \\
\hline$m$ & mass of adsorbent $(\mathrm{g})$ \\
\hline$q$ & the adsorbed mass of metal ion per gram of adsorbent $\left(\mathrm{mmol} \cdot \mathrm{g}^{-1}\right)$ \\
\hline$R$ & universal gas constant $\left(8.314 \times 10^{-3} \mathrm{~kJ}(\mathrm{~K} . \mathrm{mol})^{-1}\right)$ \\
\hline$T$ & temperature $(\mathrm{K})$ \\
\hline$V$ & volume of solution $(\mathrm{L})$ \\
\hline
\end{tabular}

